\title{
Bevordert een intrinsieke arbeidsoriëntatie de bevlogenheid en arbeidstevredenheid?
}

Citation for published version (APA):

Van Ruysseveldt, J., De Witte, H., \& Smulders, P. (2009). Bevordert een intrinsieke arbeidsoriëntatie de bevlogenheid en arbeidstevredenheid? Gedrag \& Organisatie, 22(3), 177-199.

https://www.gedragenorganisatie.nl/inhoud/tijdschrift_artikel/GO-22-3-1/Bevordert-een-intrinsieke-arbeidsorintatie-de-bevlogenheid-en-arbeidstevredenheid

Document status and date:

Published: 01/01/2009

Document Version:

Peer reviewed version

Document license:

CC BY-NC-ND

Please check the document version of this publication:

- A submitted manuscript is the version of the article upon submission and before peer-review. There can be important differences between the submitted version and the official published version of record. People interested in the research are advised to contact the author for the final version of the publication, or visit the DOI to the publisher's website.

- The final author version and the galley proof are versions of the publication after peer review.

- The final published version features the final layout of the paper including the volume, issue and page numbers.

Link to publication

\section{General rights}

Copyright and moral rights for the publications made accessible in the public portal are retained by the authors and/or other copyright owners and it is a condition of accessing publications that users recognise and abide by the legal requirements associated with these rights.

- Users may download and print one copy of any publication from the public portal for the purpose of private study or research.

- You may not further distribute the material or use it for any profit-making activity or commercial gain

- You may freely distribute the URL identifying the publication in the public portal.

If the publication is distributed under the terms of Article 25fa of the Dutch Copyright Act, indicated by the "Taverne" license above, please follow below link for the End User Agreement:

https://www.ou.nl/taverne-agreement

Take down policy

If you believe that this document breaches copyright please contact us at:

pure-support@ou.nl

providing details and we will investigate your claim.

Downloaded from https://research.ou.nl/ on date: 26 Apr. 2023 


\section{Bevordert een intrinsieke arbeidsoriëntatie de bevlogenheid en}

\section{arbeidstevredenheid?}

Joris Van Ruysseveldt, Hans De Witte en Peter Smulders

Joris Van Ruysseveldt

Open Universiteit Nederland

Faculteit Psychologie

Postbus 2960

NL-6401 DL Heerlen

++ 31-45-576.28.39

joris.vanruysseveldt@ou.nl

Aantal woorden: 7259 (exclusief tabellen en figuren) 


\section{Adresgegevens}

Joris Van Ruysseveldt

Open Universiteit Nederland

Faculteit Psychologie

Postbus 2960

NL-6401 DL Heerlen

++ 31-45-576.28.39

joris.vanruysseveldt@ou.nl

\section{Hans De Witte}

Katholieke Universiteit Leuven

Departement psychologie

Tiensestraat 102

B-3000 Leuven

Hans.dewitte@psy.kuleuven.be

Peter Smulders

TNO

PB 718

2130 AS Hoofddorp

Peter.smulders@tno.nl 


\section{Samenvatting}

Speelt een intrinsieke arbeidsoriëntatie een rol als persoonlijke hulpbron in de relatie tussen werkeisen en hulpbronnen enerzijds en arbeidstevredenheid en bevlogenheid anderzijds? Dit is onderzocht in een omvangrijke, representatieve steekproef van de Nederlandse beroepsbevolking $(\mathrm{N}=4009)$. Op grond van veronderstellingen afgeleid uit het Job Demands-Resources model zijn hoofd- en moderatie-effecten van een intrinsieke arbeidsoriëntatie verwacht. Een hoofdeffect van intrinsieke arbeidsoriëntatie werd wel gevonden voor de bevlogenheid, maar niet voor de arbeidstevredenheid. Tevens bleek dat een intrinsieke arbeidsoriëntatie de positieve samenhang tussen autonomie, ontwikkelingsmogelijkheden en taakcomplexiteit enerzijds en bevlogenheid én arbeidstevredenheid anderzijds versterkte en de relatie tussen werkdruk en bevlogenheid bufferde. Mogelijke verklaringen voor de gevonden moderatie-effecten zijn gegeven. Ten slotte bevestigde het onderzoek dat werkkenmerken de belangrijkste voorspellers zijn van bevlogenheid en arbeidstevredenheid.

Trefwoorden: persoonlijke hulpbronnen, werkwaarden, JD-R model, bevlogenheid, leermogelijkheden

\section{Summary}

What role does an intrinsic work orientation, conceptualized as personal resource, play in the relationship between job demands and resources on the one hand and job satisfaction an work engagement on the other? This has been studied in a large, representative sample of the Dutch working population $(\mathrm{N}=4009)$. Based on assumptions of the Job Demands-Resources model both main and moderating effects of an intrinsic work orientation were expected. A main effect of an intrinsic work orientation was found for work engagement, but not for satisfaction. Furthermore an intrinsic work orientation boosted the positive effect of autonomy, learning opportunities and task complexity on engagement and job satisfaction, and buffered the relationship between workload and engagement. Explanations for these findings were elaborated. Finally work characteristics were the strongest predictors of engagement and job satisfaction.

Key words: personal resources, work values, JD-R model, work engagement, learning opportunities 


\section{Bevordert een intrinsieke arbeidsoriëntatie de bevlogenheid en arbeidstevredenheid?}

\section{Inleiding}

Welke invloed oefent een intrinsieke arbeidsoriëntatie uit op de bevlogenheid en arbeidstevredenheid van Nederlandse werknemers? Arbeidsoriëntaties verwijzen naar het belang of de waarde die werknemers toekennen aan specifieke aspecten van het werk (Van Hoof, Bruin, Schoemaker \& Vroom, 2002; Achterberg, Houtman \& Jetten, 2003; Evers, Ybema \& Smulders, 2006) ${ }^{1}$. Een intrinsieke arbeidsoriëntatie betekent dat de werknemer een hoge waarde toekent aan inhoudelijke aspecten van het werk, zoals zelfstandigheid, uitdaging, en mogelijkheden tot zelfontplooiing (Feather \& O’Brien, 1986; Malka \& Chatman, 2003). Een extrinsieke arbeidsoriëntatie betekent dat de werknemer veel waarde hecht aan de opbrengsten van het werk, zoals inkomen, status, en gunstige arbeidsomstandigheden.

De afgelopen jaren is het verband tussen arbeidsoriëntaties en arbeidstevredenheid door verschillende Nederlandse onderzoekers onderzocht (zie bijvoorbeeld Houkes, Janssen, De Jonge \& Bakker, 2003; Achterberg et al., 2003). Meestal is daarbij het Vitaminemodel van Warr (1994) als verklarend model en arbeidstevredenheid als de onderzochte afhankelijke variabele gehanteerd (Taris \& Feij, 2001; Boer, De Jonge \& Hamers, 2003; Evers et al., 2006). Kort samengevat is door de genoemde onderzoekers de veronderstelling getoetst dat de arbeidstevredenheid het hoogst is bij een match tussen een hoge intrinsieke arbeidsoriëntatie en de aanwezigheid van intrinsieke taakaspecten zoals autonomie en ontwikkelingsmogelijkheden, en het laagst bij een mismatch.

Dit onderzoek wijkt in minstens twee opzichten af van de genoemde onderzoeken en wil daarmee een bijdrage leveren aan de verdere ontwikkeling van de kennis op dit 
onderzoeksdomein. Ten eerste nemen we in dit onderzoek naast arbeidstevredenheid ook bevlogenheid als afhankelijke variabele op waardoor een 'dubbele' toetsing van het onderzoeksmodel mogelijk wordt. Beide welzijnaspecten vullen elkaar aan: terwijl arbeidstevredenheid een eerder hedonistisch aspect van welzijn representeert waarin positieve emoties centraal staan, kan bevlogenheid beschouwd worden als een energetische, eudaimonische vorm van welzijn (Deci \& Ryan, 2000; Schaufeli \& Bakker, 2001).

Ten tweede steunt het onderzoeksmodel op veronderstellingen ontleend aan het Job Demands-Resources (JD-R) model (Demerouti, Nachreiner, Bakker \& Schaufeli, 2001; Xanthopoulou, Bakker, Demerouti \& Schaufeli, 2007; Bakker \& Demerouti, 2007). Dit in tegenstelling tot de eerder genoemde onderzoeken die zich overwegend situeren in de traditie van de fitmodellen (French, Kaplan \& Harrison, 1982; Roberts \& Robins, 2004), in het bijzonder van het Vitaminemodel van Warr (1994). Naast werkkenmerken integreert Warr in zijn Vitaminemodel ook persoonsgebonden kenmerken zoals vaardigheden en werkwaarden/arbeidsoriëntaties. Enerzijds beïnvloeden deze persoonsgebonden kenmerken de werkkenmerken, bijvoorbeeld als gevolg van processen van zelfselectie: werknemers met bepaalde werkwaarden zullen geneigd zijn werk te zoeken dat past bij hun waarden (Evers et al., 2006: 38$)^{2}$. Anderzijds modereren de persoonsgebonden kenmerken de relatie tussen de werkkenmerken en mentale gezondheid (Warr, 1994: 90). Daaraan ligt het principe van de matching characteristics ten grondslag: wanneer een bepaald werkkenmerk in het werk aanwezig is, zal het effect van dat kenmerk op de mentale gezondheid sterker zijn naarmate de werknemer veel belang hecht aan de bijpassende werkwaarde. Zo hangt meer afwisseling in het werk samen met een betere mentale gezondheid, maar die samenhang is sterker wanneer de werknemer een hoge waarde hecht aan afwisseling in het werk (in vergelijking met de situatie waarin hij/zij daar weinig waarde aan hecht). 
Om twee redenen is in dit onderzoek de traditie van de fitmodellen verlaten en gekozen voor het JD-R model. In de eerste plaats is in Nederlands onderzoek slechts gedeeltelijk empirische steun gevonden voor de veronderstellingen van Warr. Zo vinden Evers et al. (2006) voor een representatieve steekproef uit de Nederlandse beroepsbevolking in slechts drie van de zeven gevallen dat de fit van een werkkenmerk en de bijhorende werkwaarde tot een significant hogere arbeidstevredenheid leidt: namelijk voor complex werk/belang interessant werk, voor afwisseling/belang afwisselend werk en voor baanzekerheid/belang zekerheid. Ook Taris en Feij (2001) vinden in hun onderzoek onder Nederlandse jongvolwassenen slechts gedeeltelijk steun voor het modererende effect van werkwaarden op de relatie tussen werkkenmerken en werkuitkomsten. Ten slotte vinden Boer et al. (2003) in een onderzoek onder werknemers in de zorgsector in vier van de acht veronderstelde gevallen een significant modererend effect van arbeidsoriëntaties op de relatie tussen werkkenmerken enerzijds en arbeidstevredenheid en werkmotivatie anderzijds.

In de tweede plaats verwachten we dat het JD-R model betere aangrijpingspunten biedt voor een genuanceerder en verfijnder inzicht in de samenhang tussen een intrinsieke arbeidsoriëntatie, het werk en de uitkomsten daarvan, dan Warr's principe van de matching characteristics. Dat is het gevolg van het feit dat in het JD-R model binnen de werkkenmerken een nader onderscheid wordt aangebracht tussen werkeisen en hulpbronnen (zie verder), dat moderatie-effecten tussen werkeisen en hulpbronnen worden verondersteld (zie verder) en dat relevante persoonsgebonden kenmerken als persoonsgebonden hulpbron zijn opgevat en daarmee allerlei theoretische veronderstellingen zijn te verbinden. Door een intrinsieke arbeidsoriëntatie te conceptualiseren als een persoonsgebonden hulpbron kan vanuit het JD-R model zowel een hoofdeffect op bevlogenheid en arbeidstevredenheid afgeleid worden, als een 'dubbel' modererend effect, namelijk een bufferend effect van een intrinsieke arbeidsoriëntatie op de relatie tussen de werkdruk en bevlogenheid/arbeidstevredenheid, en een versterkend effect ervan 
op de relatie tussen de hulpbronnen (autonomie, ontwikkelingsmogelijkheden en complexiteit) en bevlogenheid/arbeidstevredenheid. We onderzoeken hier of deze veronderstellingen opgaan voor een omvangrijke en heterogeen samengestelde steekproef uit de Nederlandse beroepsbevolking, de TNO Arbeidssituatie Survey TAS (Smulders, Andries \& Otten, 2001).

\section{Een intrinsieke arbeidsoriëntatie als persoonsgebonden hulpbron in het JD-R model}

Arbeidsoriëntaties zijn nog niet eerder in het kader van het JD-R model onderzocht. Echter, door ze op te vatten als een persoonsgebonden hulpbron komt de weg naar een dergelijk onderzoek open te liggen. Alvorens te argumenteren waarom een intrinsieke arbeidsoriëntatie als persoonsgebonden hulpbron geconceptualiseerd kan worden, dienen eerst de drie kernassumpties van het JD-R model samengevat te worden.

Het JD-R model gaat er ten eerste vanuit dat werkkenmerken onder te brengen zijn in twee brede categorieën. Werkeisen omvatten alle fysieke, sociale of organisationele aspecten van het werk die een volgehouden fysieke of mentale inspanning vereisen en die om die reden verbonden zijn met specifieke fysiologische en psychologische kosten voor de werknemer, zoals uitputting. Hulpbronnen, omvatten alle fysieke, psychologische, sociale of organisationele aspecten van het werk die (a) bijdragen aan het realiseren van de taakdoelstellingen, (b) de aanwezige werkeisen en de fysiologische en psychologische kosten die ermee verbonden zijn reduceren, en (c) persoonlijke groei en ontwikkeling stimuleren (Demerouti et al., 2001).

Ten tweede hangen werkeisen en hulpbronnen elk samen met specifieke uitkomsten, en dat als gevolg van het optreden van twee parallelle processen (Schaufeli \& Bakker, 2004: 297 299). In het energetische of stressproces leiden de veeleisende aspecten van het werk tot een voortdurende aantasting van de energiereserves van de taakuitvoerder, en daarmee op de lange duur tot chronische vermoeidheid en uitputting. Het tweede proces is motivationeel van aard: hulpbronnen, zoals zelfstandigheid in het werk, hebben een hoog motiverend potentieel doordat 
ze de behoefte van de werknemer aan persoonlijke groei en ontwikkeling stimuleren en helpen realiseren. Daarnaast spelen ze een extrinsiek motiverende rol omdat ze het de werknemer mogelijk maken diens taakdoelstellingen te realiseren. Dit tweede proces leidt tot een positieve psychische toestand bij de werknemer die bevlogenheid wordt genoemd.

Ten derde kunnen volgens het JD-R model allerlei werkeisen en hulpbronnen interacteren en zo tot verminderde uitputting en verhoogde motivatie leiden. De beschikbaarheid over veel hulpbronnen buffert het negatieve effect van de werkeisen op uitputting, en omgekeerd dempen werkeisen het positieve effect van hulpbronnen op bevlogenheid.

Het JD-R model is meermaals in empirisch onderzoek getoetst (bijvoorbeeld Demerouti et al., 2001; Schaufeli \& Bakker, 2004b; Bakker \& Demerouti, 2007; Van Ruysseveldt, Smulders \& Taverniers, 2008; Van Ruysseveldt, Taverniers \& Smulders, 2009) en de plausibiliteit van de kernassumpties staat inmiddels buiten discussie: werkeisen zijn de belangrijkste predictoren van negatieve werkuitkomsten zoals emotionele uitputting en hulpbronnen van positieve werkuitkomsten zoals bevlogenheid. Onze eerste veronderstelling luidt:

H1: werkdruk (de werkeis) heeft een significant negatief en autonomie, ontwikkelingsmogelijkheden en complexiteit (de hulpbronnen) hebben een significant positief hoofdeffect op de arbeidstevredenheid/bevlogenheid.

Recent is de aandacht in het JD-R model voor de rol van persoonsgebonden kenmerken sterk toegenomen (Bakker \& Demerouti, 2007). Xanthopoulou et al. (2007, 2008) ontwikkelden en toetsten een versie van het model waarin ook personal resources (hier vertaald als persoonsgebonden hulpbronnen) zijn geïntegreerd. Deze omschrijven zij als persoonsgebonden aspecten die in het algemeen positief gekoppeld zijn aan veerkracht/herstellingsvermogen, en die verwijzen naar het vermogen van een persoon om diens omgeving succesvol te beheersen en te 
beïnvloeden. Voor de theoretische onderbouwing van de veronderstelde effecten tussen persoonsgebonden kenmerken, werkeisen, hulpbronnen en werkuitkomsten wordt een beroep gedaan op de Conservation of Resources (COR) theorie van Hobfoll. Naast objecten, omstandigheden en energiebronnen beschouwt Hobfoll (2002) ook persoonsgebonden kenmerken als resources, namelijk als entiteiten die door de eigenaar gewaardeerd worden om zichzelf (inherente waarde), of als middel in het realiseren van gewaardeerde doelen. Resources stellen personen in staat beter om te gaan met bedreigende omstandigheden en beschermen hen tegen de negatieve effecten van die omstandigheden (Hobfoll, 2002: 312).

Persoonlijke hulpbronnen hebben een vergelijkbaar effect op de bevlogenheid/arbeidstevredenheid als de werkgerelateerde hulpbronnen (Xanthopoulou et al., 2008), zoals beschreven bij de kernassumpties van het JD-R model. Aan de persoonsgebonden hulpbronnen is een hoog intrinsiek motiverend potentieel verbonden doordat ze de behoefte van de werknemer aan persoonlijke groei en ontwikkeling stimuleren en helpen realiseren. Bovendien neemt, naarmate de werknemer meer beschikt over dergelijke persoonsgebonden hulpbronnen, zijn of haar beheersingsvermogen over de omgeving toe, kan hij of zij effectiever omgaan met veeleisende omstandigheden, waardoor een negatieve samenhang met werkstress en een positieve samenhang met arbeidstevredenheid/bevlogenheid tot stand komt. In verschillende onderzoeken is een positief hoofdeffect van de persoonsgebonden hulpbronnen (in het bijzonder self-efficacy en self-esteem) op bevlogenheid gevonden (Xanthopoulou et al., 2007, Mauno, Kinnunen \& Ruokolainen, 2007; Xanthopoulou et al., 2008). Voor wat betreft een intrinsieke arbeidsoriëntatie is in buitenlands onderzoek empirische evidentie gevonden voor een negatief hoofdeffect op werkstress (Knoop, 2001; Baker, 2004; vgl. Vansteenkiste, Neyrinck, Niemec, Soenens, De Witte, \& Van den Broeck, 2007; Van Ruysseveldt \& Smulders, 2008) en een positief hoofdeffect op arbeidstevredenheid (Lu, 1999), terwijl de samenhang tussen een 
intrinsieke arbeidsoriëntatie en bevlogenheid nog niet eerder onderzocht is. Uit het voorafgaande is de volgende veronderstelling afgeleid:

$\underline{\mathrm{H} 2}$ : Een intrinsieke arbeidsoriëntatie heeft een significant positief hoofdeffect op de arbeidstevredenheid/bevlogenheid.

Xanthopoulou et al. (2007: 124-125) veronderstellen verder dat persoonsgebonden hulpbronnen in het motivationeel proces een rol spelen als mediator in de relatie tussen hulpbronnen en bevlogenheid ${ }^{3}$. Het opereren binnen omgevingen waarin veel hulpbronnen aanwezig zijn, activeert de persoonsgebonden hulpbronnen van de werknemer, en dat resulteert vervolgens in positieve psychologische en organisationele uitkomsten. De beschikbaarheid in de werksituatie van werkgerelateerde hulpbronnen heeft tot gevolg dat de werknemer zich trefzekerder, belangrijker voor de organisatie en optimistischer over de toekomst voelt, en in het werk meer bevlogen en gemotiveerd geraakt. Xanthopoulou et al. (2007) onderzochten bij een steekproef van 714 Nederlandse werknemers van een elektronicabedrijf het effect van drie persoonsgebonden hulpbronnen: self-efficacy, self-esteem en optimisme. De resultaten bevestigen de rol van deze drie persoonsgebonden kenmerken als mediator in de relatie tussen hulpbronnen en bevlogenheid.

Wat betreft het energetische of stressproces veronderstellen Xanthopoulou et al. (2007) dat persoonsgebonden hulpbronnen een rol als moderator spelen in de relatie tussen werkeisen en uitputtingsverschijnselen. Persoonlijke hulpbronnen zouden een vergelijkbaar bufferend effect hebben als de werkgerelateerde hulpbronnen. In hun onderzoek vinden Xanthopoulou et al. (2007) voor self-efficacy, self-esteem en optimisme geen empirische evidentie voor het buffereffect. Door Van Ruysseveldt en Smulders (2008) is voor wat betreft een intrinsieke arbeidsoriëntatie, wel empirische evidentie gevonden. Interessant is daarom te onderzoeken of 
een intrinsieke arbeidsoriëntatie ook in het motivationeel proces een bufferende rol speelt in de relatie tussen werkeisen en bevlogenheid/arbeidstevredenheid. De veronderstelling luidt:

H3: Een hoge intrinsieke arbeidsoriëntatie buffert het negatieve hoofdeffect van de werkeisen op de arbeidstevredenheid/bevlogenheid: naarmate men sterker intrinsiek georiënteerd is, leidt een toename in de werkeisen niet of in mindere mate tot een daling van de arbeidstevredenheid/bevlogenheid.

Aan de voorafgaande veronderstellingen, die nauw aansluiten bij de kernassumpties van het JDR model, voegen we nog een vierde toe, afgeleid uit de Expectancy-Value Theory (EVT) van Vroom (1964). Volgens EVT beïnvloeden (werk)waarden de percepties, attitudes en gedragingen van individuen (Feather, 1992). Ze spelen een rol in de wijze waarop personen de situatie waarin ze zich bevinden, construeren, ertoe aangetrokken worden en er zich in gedragen (Feather, 1999). In het verlengde hiervan veronderstellen we dat een intrinsieke arbeidsoriëntatie de cognitieve gevoeligheid voor de beschikbare werkgerelateerde hulpbronnen zoals autonomie en ontwikkelingsmogelijkheden vergroot, en als gevolg daarvan een effectievere benutting van die hulpbronnen bevordert. Een intrinsieke arbeidsoriëntatie speelt bij wijze van spreken een 'activerende' rol: sterk intrinsiek georiënteerde werknemers slagen er beter in om de mogelijkheden voor autonomie en persoonlijke ontwikkeling in de werkomgeving waar te nemen, te interpreteren en in het verlengde daarvan operationeel te maken in het omgaan met hoge werkeisen. Intrinsiek georiënteerden staan meer open voor nieuwe ideeën, ervaringen en handelingen en bouwen kennis en cognitieve vermogens op (Fredrickson, 2001; Baker, 2004). Met die toegenomen kennis en cognitieve vermogens slagen ze erin de werkgerelateerde hulpbronnen doelmatiger te benutten (Vansteenkiste et al., 2007). Op deze inzichten baseren we de veronderstelling dat een intrinsieke arbeidsoriëntatie zorgt voor een verhoging in het effect 
van de werkgerelateerde hulpbronnen op de arbeidstevredenheid/bevlogenheid. Voor wat het energetische proces betreft is door Van Ruysseveldt en Smulders (2008) empirische evidentie gevonden voor het versterkend effect van een intrinsieke arbeidsoriëntatie op de relatie tussen autonomie, ontwikkelingsmogelijkheden en complexiteit enerzijds en emotionele uitputting anderzijds. Hier bekijken we of een dergelijk versterkend effect ook in het motivationeel proces waargenomen kan worden.

H4: Een intrinsieke arbeidsoriëntatie versterkt het positieve hoofdeffect van de hulpbronnen op de arbeidstevredenheid/bevlogenheid: naarmate een werknemer sterker intrinsiek georiënteerd is, leidt een toename in de hulpbronnen tot een sterkere toename van de arbeidstevredenheid/bevlogenheid.

\section{Onderzoeksmodel}

De onderzoeksvragen in dit onderzoek luiden: (1) welke rol speelt een intrinsieke arbeidsoriëntatie bij het bevorderen van de arbeidstevredenheid en bevlogenheid, en (2) vervult een intrinsieke arbeidsoriëntatie een rol als moderator in de relatie tussen werkeisen/hulpbronnen en arbeidstevredenheid/bevlogenheid? In het onderzoeksmodel (figuur 1) zijn twee afhankelijke variabelen opgenomen. Zoals eerder vermeld is in het bestaande (Nederlandse) onderzoek meestal arbeidstevredenheid als afhankelijke variabele gehanteerd. Omdat het hier toegepaste onderzoeksmodel steunt op het JD-R model en in dat model bevlogenheid als een prominente operationalisatie voor de positieve werkuitkomsten wordt gebruikt, is in de analyses ook die afhankelijke variabele ingevoerd. Dat biedt tevens een mogelijkheid tot 'dubbele' toetsing van het onderzoeksmodel.

Figuur 1 
Dit onderzoek richt zich op de werkdruk - als een van de belangrijkste werkeisen (Van Ruysseveldt et al., 2009) - en op drie werkgerelateerde hulpbronnen: autonomie, ontwikkelingsmogelijkheden en taakcomplexiteit die allen een sterke samenhang met bevlogenheid vertonen (Van Ruysseveldt et al., 2008). Taakcomplexiteit verwijst naar werk dat een hoge concentratie en doelgerichte informatieverwerking vereist en kan ook opgevat worden als het tegenovergestelde van eenvoudig, routinematig werk. Omdat dergelijk werk veel taken omvat die een beroep doen op de cognitieve vermogens en competenties van de taakuitvoerder, kent het een sterk uitdagend en motiverend karakter. In onderzoek is een positieve samenhang met arbeidstevredenheid (bijvoorbeeld Judge, Bono \& Locke, 2000) en bevlogenheid (bijvoorbeeld Van Ruysseveldt et al., 2008) gevonden.

In het onderzoeksmodel is verondersteld dat intrinsieke arbeidsoriëntatie de effecten van autonomie, ontwikkelingsmogelijkheden en taakcomplexiteit op arbeidstevredenheid/bevlogenheid versterkt. Tevens is verondersteld dat een hoge intrinsieke arbeidsoriëntatie het negatieve hoofdeffect van de werkdruk op de arbeidstevredenheid/bevlogenheid buffert.

\section{Methode}

\section{Dataverzameling en steekproef}

De TNO Arbeidssituatie Survey (TAS) is een schriftelijke cross-sectionele survey die iedere twee jaar de arbeidssituatie in een toevalssteekproef uit de Nederlandse beroepsbevolking meet (Smulders et al., 2001). Bij het samenstellen van deze TAS-steekproeven vormt de Respondenten Databank van Bureau Intomart (die omvatte in 200245.000 Nederlanders van 15 jaar of ouder die betaald werk verrichten) het uitgangspunt. Uit de Respondenten Databank 
is een gestratificeerde (via provincie, leeftijd, geslacht en opleiding) aselecte steekproef getrokken van 8500 personen (brutosteekproef) (zie voor nadere toelichting bij de wijze van steekproeftrekking: Smulders et al., 2001: 30). In 2002 omvatte de nettosteekproef 4009 personen (respons van 45\%). Vervolgens is weging toegepast om de nettosteekproef zo maximaal mogelijk in lijn te brengen met de 'gouden standaard', de Enquête Beroepsbevolking (EBB) van het Centraal Bureau voor de Statistiek (zie voor toelichting bij de weging: Smulders et al., 2001: 33-40). De respondentenverdeling in de TAS komt daardoor goed overeen met die in de $\mathrm{EBB}^{4}$.

\section{Meetinstrumenten (schalen)}

\section{Controlevariabelen: sociaaldemografische kenmerken}

In de statistische analyses is steeds gecontroleerd voor vier sociaaldemografische kenmerken: geslacht, leeftijd, onderwijsniveau en contractuele wekelijkse arbeidsduur. Uit eerder onderzoek (Van Ruysseveldt \& Smulders, 2008: 276-277) is gebleken dat deze sociaaldemografische kenmerken een significant en soms sterk hoofdeffect hebben op zowel de arbeidsoriëntaties als de arbeidstevredenheid.

\section{De werkkenmerken}

Alle werkkenmerken zijn gemeten op een vierpuntsschaal variërend van 1 (nooit) tot 4 (altijd).

Werkdruk is gemeten met vijf items die ontleend zijn aan de werkdrukschaal van Karasek (1979; Karasek \& Theorell, 1990) en die een indicatie geven van de kwantitatieve werkdruk. Een voorbeelditem is: 'Moet u erg snel werken?'

Complexiteit van het werk meet aan de hand van vijf items de mate waarin het werk concentratie en informatieverwerking vereist; complex werk is op te vatten als het 
tegenovergestelde van eenvoudig, routinematig werk dat weinig denkwerk impliceert. De vragen zijn ontleend aan Houtman et al. (1995). Een voorbeelditem is: 'Vergt uw werk dat u er uw gedachten bijhoudt?'

Autonomie in het werk is gemeten aan de hand van vijf items die een variant zijn op de decision latitude- vragen uit de Job Content Questionnaire van Karasek. Ze zijn bewerkt en vertaald door Goudswaard, Dhondt en Kraan (1998). Een voorbeelditem is: 'Kunt u zelf beslissen hoe u uw werk uitvoert?'

De ontwikkelingsmogelijkheden zijn gemeten met vijf items die de mate indiceren waarin het werk aansluit bij ontwikkelde kennis en vaardigheden en de mate waarin de taakuitvoerder wordt geprikkeld om zich in het werk verder te ontwikkelen (cfr. skill discretion bij Karasek, 1979) (Houtman et al., 1995; Goudswaard et al., 1998). Een voorbeelditem is: 'Vereist uw baan dat u nieuwe dingen leert?'

\section{Intrinsieke en extrinsieke arbeidsoriëntaties}

Aan de respondenten is gevraagd op een vierpuntsschaal, variërend van 1 (niet erg belangrijk) tot 4 (heel erg belangrijk), aan te geven in welke mate zij bepaalde aspecten van het werk in het algemeen waarderen. De vraag luidde exact: 'Kunt $\mathrm{u}$ aangeven welke aspecten $\mathrm{u}$ belangrijk en welke u minder belangrijk vindt bij het beoordelen van een baan in het algemeen?'. Intrinsieke arbeidsoriëntatie is gemeten als de mate waarin de werknemer volgende aspecten van het werk in hoge mate waardeert: zelfstandigheid, variatie, leer- en groeimogelijkheden, interessant werk en iets bereiken. Extrinsieke arbeidsoriëntatie is gemeten als het belang dat de werknemer hecht aan volgende aspecten van het werk: goede beloning, goede arbeidsomstandigheden, zekerheid en geschikte werktijden. Deze items zijn ontleend aan de Motivator-Hygiene Two-factor Theory van Herzberg (1959). Met confirmatorische factoranalyse (Amos 5) (Arbucle \& Worthke, 1999) is de constructvaliditeit 
van de schalen intrinsieke en extrinsieke arbeidsoriëntatie onderzocht. Model 1 omvat slechts een latente factor, waaraan alle items betreffende intrinsieke en extrinsieke arbeidsoriëntatie zijn gerelateerd. Model 2 onderscheidt twee latente factoren, een voor de items die intrinsieke arbeidsoriëntatie meten en een voor de items die extrinsieke arbeidsoriëntatie meten. Voor de absolute fit indices (RMSEA) wordt een score van .08 beschouwd als indicatief voor een bevredigende modelfit, en een score minder dan .05 betekent een erg goede fit (Steiger, 1990). Voor de relatieve fit indices (CFI, NNFI) wijzen scores hoger dan .90 op een goede fit (Byrne, 2001). Het 1-factormodel vertoont geen acceptabele fit met de data ${ }^{5}$, het 2 factorenmodel daarentegen wel. De fitstatistieken voor dit model zijn als volgt: $\chi^{2}=238.64$, $\mathrm{df}=19, p<.001, \mathrm{CFI}=.95, \mathrm{NNFI}=.92$ en $\mathrm{RMSEA}=.054(90 \% \mathrm{CI}=.048$ tot .060$)$.

In het regressiemodel (maar niet in het onderzoeksmodel) is naast de mate van intrinsieke arbeidsoriëntatie ook de mate van extrinsieke arbeidsoriëntatie opgenomen. Uit eerder onderzoek (Vansteenkiste et al., 2007: 260; De Witte, 2000) blijkt dat beide oriëntaties onderling matig positief samenhangen. Theoretisch sluit de ene oriëntatie de andere niet uit: werknemers kunnen tezelfdertijd sterk intrinsiek en sterk extrinsiek georiënteerd zijn. Vanuit methodologisch standpunt kan deze bevinding ook een artefact zijn van het belang dat werknemers hechten aan werk in het algemeen. Het is mogelijk dat respondenten die werk in het algemeen belangrijk vinden, zowel intrinsieke als extrinsieke werkaspecten hoog waarderen, niet omwille van die aspecten zelf, maar omdat ze allemaal verbonden zijn met werk. In dat geval worden geen afzonderlijke arbeidsoriëntaties gemeten, maar een ander construct, zoals werkcentraliteit (zie Van Hoof et al., 2002). Om de mate van intrinsieke arbeidsoriëntatie zo trefzeker mogelijk te meten, is het om methodologische redenen belangrijk bij het analyseren van de effecten van een intrinsieke arbeidsoriëntatie te controleren voor extrinsieke arbeidsoriëntatie.

\section{De afhankelijke variabelen}


Bevlogenheid is gemeten aan de hand van tien items (een ingekorte versie van de Utrechtse Bevlogenheidsschaal UBES). Een voorbeelditem is: 'Op mijn werk bruis ik van energie'. Antwoorden kan op een zevenpuntsschaal gaande van 0 (nooit) tot 6 (dagelijks).

Arbeidstevredenheid is gemeten aan de hand van een item: 'In welke mate bent $\mathrm{u}$ - alles bij elkaar genomen - tevreden met uw werk?' Antwoorden kan op een vijfpuntsschaal gaande van 1 (zeer ontevreden) tot 5 (zeer tevreden).

\section{Analyses}

Eerst is de interne consistentie van de gehanteerde schalen gecontroleerd (zie diagonaal in tabel 1). Met Cronbach's $\alpha$ tussen .74 en .92 zijn de gebruikte schalen als betrouwbaar te bestempelen. De hypothesen zijn getest aan de hand van hiërarchische regressieanalyses. In een eerste stap is een regressiemodel berekend met de werkkenmerken en intrinsieke en extrinsieke arbeidsoriëntatie. Om het risico uit te sluiten dat op 'goed geluk' of op 'kanskapitalisatie-achtige' wijze significante interactietermen worden aangetroffen, is vervolgens elk van de veronderstelde interactietermen afzonderlijk aan het additieve model toegevoegd. De interactietermen zijn berekend als het product van de gecentraliseerde schaalscores.

\section{Resultaten}

In tabel 1 zijn de correlaties tussen de onafhankelijke en afhankelijke variabelen weergegeven. Intrinsieke arbeidsoriëntatie vertoont een significante positieve samenhang met arbeidstevredenheid en bevlogenheid. Zoals verwacht hangen intrinsieke en extrinsieke arbeidsoriëntaties onderling matig positief samen $(\mathrm{r}=.30, p<.01)$. Een intrinsieke arbeidsoriëntatie sluit een extrinsieke arbeidsoriëntatie niet uit. Bij het bestuderen van het effect van de ene soort arbeidsoriëntaties moet in de analyses gecontroleerd worden voor de andere soort (Vansteenkiste et al., 2007). Verder hangen werkdruk negatief en autonomie, 
ontwikkelingsmogelijkheden, taakcomplexiteit en een intrinsieke arbeidsoriëntatie positief significant samen met zowel arbeidstevredenheid als bevlogenheid.

Tabel 1

In tabel 2 zijn de resultaten van de multipele regressieanalyse voor de afhankelijke variabele arbeidstevredenheid en in tabel 3 die voor de afhankelijke variabele bevlogenheid weergegeven. De onafhankelijke variabelen verklaren samen $11 \%$ van de totale variantie in arbeidstevredenheid en $34 \%$ van de totale variantie in bevlogenheid.

Tabellen 2 en 3

Zoals verwacht in $\mathrm{H} 1$ hangt werkdruk significant negatief samen met arbeidstevredenheid en bevlogenheid. Autonomie, taakcomplexiteit en vooral ontwikkelingsmogelijkheden (de hulpbronnen) hangen significant positief samen met arbeidstevredenheid en bevlogenheid.

De veronderstelling geformuleerd in $\mathrm{H} 2$ krijgt slechts gedeeltelijke empirische ondersteuning. Een intrinsieke arbeidsoriëntatie vertoont wel een significante positieve samenhang met bevlogenheid, maar niet met arbeidstevredenheid. Hetzelfde geldt voor H3: een intrinsieke arbeidsoriëntatie heeft wel een bufferend effect op de relatie tussen werkdruk en bevlogenheid, maar niet op de relatie tussen werkdruk en arbeidstevredenheid. Het verloop van dat interactie-effect op de relatie tussen werkdruk en bevlogenheid is grafisch weergegeven in figuur 2A. De daling in bevlogenheid als gevolg van een toename in de werkdruk blijft voor sterk intrinsiek georiënteerden beperkter dan voor zwak intrinsiek georiënteerden.

Figuren 2A-D 
Voor H4 is wel over de gehele lijn empirische bevestiging gevonden. Een intrinsieke arbeidsoriëntatie heeft wel een significant versterkend effect op de relatie tussen elk van de hulpbronnen en arbeidstevredenheid. Het verloop van deze moderatie-effecten is grafisch weergegeven in figuren 3A-C. Bij sterk intrinsiek georiënteerden stijgt de arbeidstevredenheid sterker bij een toename van de autonomie, ontwikkelingsmogelijkheden en taakcomplexiteit dan bij zwak intrinsiek georiënteerden. Voor sterk intrinsiek georiënteerden gaat een werksituatie gekenmerkt door weinig autonomie, ontwikkelingsmogelijkheden en complexiteit samen met minder arbeidstevredenheid dan voor zwak intrinsiek georiënteerden.

Ook heeft een intrinsieke arbeidsoriëntatie een versterkend effect op de relatie tussen autonomie, ontwikkelingsmogelijkheden en taakcomplexiteit enerzijds en bevlogenheid anderzijds: voor elke van deze werkkenmerken geldt dat de positieve relatie met bevlogenheid sterker is voor sterk intrinsiek georiënteerden dan voor zwak intrinsiek georiënteerden (zie figuren 2B-D voor het grafische verloop hiervan).

Figuren $3 \mathrm{~A}-\mathrm{C}$

\section{Samenvatting en discussie}

In deze studie is de rol van een intrinsieke arbeidsoriëntatie in de relatie tussen de werkeisen en hulpbronnen enerzijds en arbeidstevredenheid en bevlogenheid (Schaufeli \& Bakker, 2004b) anderzijds nader onderzocht. In theoretisch opzicht is aangesloten bij het JD-R model (Bakker \& Demerouti, 2007). De verwachting was dat dit model meer genuanceerde en verfijnde inzichten zou opleveren over de samenhang tussen een intrinsieke arbeidsoriëntatie, het werk en de positieve uitkomsten daarvan, dan het Vitaminemodel van Warr (1994), waarop het merendeel van het Nederlandse onderzoek op dit terrein steunt. In beide modellen worden moderatie- 
effecten verondersteld, maar uit het JD-R model is een 'dubbel' moderatie-effect af te leiden: een bufferend effect van een intrinsieke arbeidsoriëntatie op de relatie tussen werkdruk en arbeidstevredenheid/bevlogenheid en een versterkend effect op de relatie tussen drie hulpbronnen (autonomie, ontwikkelingsmogelijkheden en taakcomplexiteit) en arbeidstevredenheid/bevlogenheid. Daarnaast valt uit het JD-R model ook nog de veronderstelling van een hoofdeffect van een intrinsieke arbeidsoriëntatie op de arbeidstevredenheid/bevlogenheid af te leiden.

Hypothese 1 is geheel bevestigd: de werkdruk heeft een significant negatief effect en autonomie, ontwikkelingsmogelijkheden en taakcomplexiteit een significant positief effect op zowel arbeidstevredenheid, als bevlogenheid. In overeenstemming met de literatuur (o.a. Warr, 1994; Taris \& Feij, 2001; Achterberg et al., 2003; Xanthopoulou et al., 2007) bevestigt ons onderzoek dat deze werkkenmerken de belangrijkste voorspellers zijn van bevlogenheid en arbeidstevredenheid. Ze leveren de grootste bijdrage aan het verklaren van verschillen in arbeidstevredenheid/bevlogenheid tussen individuele werknemers.

Voor hypothese 2 is gedeeltelijk empirische steun gevonden. Een intrinsieke arbeidsoriëntatie heeft wel een significant positief hoofdeffect op bevlogenheid, maar niet op arbeidstevredenheid. Dezelfde vaststelling is gedaan ten aanzien van hypothese 3: een intrinsieke arbeidsoriëntatie buffert wel de relatie tussen werkdruk en bevlogenheid, maar niet tussen werkdruk en arbeidstevredenheid.

Hypothese 4 daarentegen wordt over de gehele lijn bevestigd: een intrinsieke arbeidsoriëntatie versterkt het positieve effect van autonomie, taakcomplexiteit en ontwikkelingsmogelijkheden op zowel bevlogenheid als arbeidstevredenheid. Bij een toename in de beschikbare hulpbronnen stijgen de bevlogenheid en arbeidstevredenheid sterker bij sterk intrinsiek georiënteerden, dan bij zwak intrinsiek georiënteerden. 


\section{Implicaties voor theorie en praktijk}

De veronderstellingen geformuleerd in de vier hypothesen krijgen volledig empirische steun voor de afhankelijke variabele bevlogenheid. Door een intrinsieke arbeidsoriëntatie in het JD-R model te integreren als een persoonsgebonden hulpbron ontstaat een genuanceerder en verfijnder inzicht in de samenhang van een intrinsieke arbeidsoriëntatie, het werk en de uitkomsten daarvan, dan op basis van het Vitaminemodel alleen. Immers, niet alleen bevordert een intrinsieke arbeidsoriëntatie de bevlogenheid, en versterkt ze de positieve samenhang tussen de werkgerelateerde hulpbronnen en de bevlogenheid; ze buffert ook de relatie tussen werkdruk en bevlogenheid. Dat laatste ondersteunt de gedachte bij Hobfoll (2002) en Xanthopoulou et al. (2007) dat personen die kunnen beschikken over (veel) persoonsgebonden hulpbronnen, beter in staat zijn met bedreigende omstandigheden om te gaan en beter beschermd zijn tegen de negatieve omstandigheden van die omstandigheden. Dergelijke persoonsgebonden hulpbronnen verhogen het vermogen van een persoon om de omgeving succesvol te beheersen en te beïnvloeden.

Het versterkende effect van een intrinsieke arbeidsoriëntatie op de relatie tussen de werkgerelateerde hulpbronnen en bevlogenheid biedt bovendien steun voor de gedachte afgeleid uit de Expectancy-Value Theory (EVT) van Vroom (1964) - dat arbeidsoriëntaties de percepties, attitudes en gedragingen van individuen beïnvloeden. Ze spelen een rol in de wijze waarop personen de situatie waarin ze zich bevinden, construeren, ertoe aangetrokken worden en er zich in gedragen (Feather, 1999).

In de omschrijving van een persoonsgebonden hulpbron (Xanthopoulou et al., 2007, 2008) is het versterkende effect vooral te verbinden met het toegenomen vermogen van een persoon om de omgeving te beïnvloeden. Intrinsiek georiënteerde werknemers kennen een hogere cognitieve gevoeligheid voor de beschikbaarheid van hulpbronnen en zijn daardoor beter in staat om de mogelijkheden tot autonomie en persoonlijke ontwikkeling die in de werksituatie 
aanwezig zijn, op te merken. Daarmee is - ten tweede - een belangrijk gevolg verbonden: omdat men de genoemde mogelijkheden beter waarneemt, kan men ze ook effectiever en optimaler benutten. Men activeert als het ware de beschikbare hulpbronnen. Het is overigens niet ondenkbaar dat intrinsiek georiënteerde werknemers een nog proactievere rol spelen in het tot stand brengen van bepaalde kenmerken van de werksituatie. Wellicht zijn ze meer geneigd inspanningen te leveren om de autonomie en ontwikkelingsmogelijkheden in het werk te bevorderen, ze zelfs af te dwingen of op eigen kracht tot stand te brengen. Die zienswijze vindt steun in het recente onderzoek van Xanthopoulou et al. (2008). De resultaten uit dit onderzoek bevestigen ook nog het nut om in het kader van het JD-R model blijvend aandacht te besteden aan de persoonsgebonden hulpbronnen, en zich niet alleen te beperken tot kenmerken van het werk.

Voor de afhankelijke variabele arbeidstevredenheid is minder empirische steun gevonden voor de veronderstellingen die afgeleid zijn uit het JD-R model. Samengevat vinden we voor die afhankelijke variabele alleen bevestiging voor het versterkende effect. Die vaststelling is conform het principe van de matching characteristics uit het Vitaminemodel van Warr (1994): de arbeidstevredenheid is het hoogst wanneer een sterke intrinsieke arbeidsoriëntatie samengaat met de aanwezigheid van veel hulpbronnen. De resultaten wijken op dit punt niet af van die uit andere Nederlands onderzoek (Taris \& Feij, 2001; Houkes et al., 2003; Achterberg et al., 2003; Boer et al., 2003; Evers et al., 2006), tenzij dat onze onderzoeksresultaten wat consistenter zijn. In theoretisch opzicht roept dit de vraag op waarom de onderzoeksresultaten uiteenlopen tussen de twee gehanteerde afhankelijke variabelen. Is dat een artefact van de gehanteerde meetmethode (item versus schaal) of zijn beide afhankelijke variabelen niet zonder meer onderling uitwisselbaar als operationalisaties voor 'positieve' werkuitkomsten? Steun voor deze laatste mogelijkheid biedt de gedachte dat bevlogenheid en arbeidstevredenheid zich op een ander abstractieniveau bevinden. Zo stelt Kahn (1990) dat bevlogenheid een meer lokaal en 
minder algemeen construct is dan arbeidstevredenheid. Bevlogenheid zou dichter tegen het werk zelf aanliggen dan arbeidstevredenheid (Christian \& Slaughter, 2007). Bevlogenheid lijkt ook meer samen te hangen met daadwerkelijke taakuitvoering, terwijl arbeidstevredenheid meer samenhangt met algemeen werkgedrag. Uit een meta-analyse van Harrison, Newman en Roth (2006) blijkt inderdaad dat patronen van werkgedrag het beste kunnen worden begrepen wanneer arbeidstevredenheid op een hoog abstractieniveau wordt geconceptualiseerd. In ons onderzoek is arbeidstevredenheid op een hoger abstractieniveau gemeten dan bevlogenheid, wat het verschil in bevindingen zou kunnen verklaren.

Bovendien blijkt uit de literatuur dat bevlogenheid en arbeidstevredenheid niet uit dezelfde componenten bestaan. May, Gilson en Harter (2004) in navolging van Kahn (1990) definiëren bevlogenheid als bestaande uit drie componenten: een fysieke component (vitaliteit), een emotionele component (toewijding) en een cognitieve component (absorptie). Het in ons onderzoek gebruikte meetinstrument, de Utrechtse Bevlogenheids Schaal (Schaufeli \& Bakker, 2004a), meet deze drie componenten ook. Arbeidstevredenheid bestaat uit een affectieve en een cognitieve component (Brief \& Weiss, 2002). De affectieve component betreft het algemene positieve of negatieve gevoel met betrekking tot het werk, de cognitieve component betreft overtuigingen of gedachten van het individu over het werk. Schleicher, Watt en Greguras (2004) constateren dat sommige meetinstrumenten voor arbeidstevredenheid meer cognitief en andere meer affectief gebaseerd zijn. Brief en Weiss (2002) constateren zelfs dat, hoewel arbeidstevredenheid in het algemeen in affectieve termen wordt geconstrueerd, veel meetinstrumenten alleen de cognitieve aspecten meten. Dit lijkt ook in ons onderzoek het geval. Het meetinstrument dat wij hebben gebruikt, bestaat uit één algemeen item, dat voornamelijk het cognitieve aspect van arbeidstevredenheid meet. Terwijl we bevlogenheid dus hebben gemeten als bestaande uit een fysieke, een cognitieve en een emotionele component, hebben we 
arbeidstevredenheid gemeten als bestaande uit louter een cognitieve component. Dit zou (mede) een oorzaak kunnen zijn voor de gevonden verschillen.

Ten slotte is een behoorlijke correlatie $(\mathrm{r}=.46 ; p<.01)$ gevonden tussen arbeidstevredenheid en bevlogenheid. Beide constructen overlappen elkaar niet helemaal. Wanneer de werkomstandigheden in orde zijn, is men waarschijnlijk wel tevreden, maar daarom geraakt men nog niet automatisch ook (erg) bevlogen. De samenhang tussen tevredenheid en bevlogenheid is wellicht mede afhankelijk van de kenmerken van de persoon en de omgeving. Interessant is meer inzicht te verwerven in de invloed van persoons- en omgevingskenmerken op de relatie tussen tevredenheid en bevlogenheid.

In dit onderzoek is een cross-sectionele onderzoeksdesign gevolgd waarbij de data tot stand is gekomen middels zelfrapportage door respondenten. Het leidt bijgevolg aan de bekende euvels van het klassieke survey-onderzoek: een risico op overschatting van de gevonden verbanden als gevolg van common method variance en het ontbreken van inzicht in de causaliteit van de gevonden verbanden. Een nadere toetsing van de veronderstelde en gevonden verbanden in longitudinaal en (quasi-)experimenteel onderzoek is daarom gewenst. Dergelijk onderzoek zou tevens een bijdrage kunnen leveren aan het vergroten van het inzicht in de wederkerigheid in de relatie tussen werkkenmerken en persoonsgebonden kenmerken. Die wederkerigheid wordt nu doorgaans geaccepteerd (Xanthopoulou et al., 2007), maar het zou nuttig zijn daar met vervolgonderzoek meer inzicht in te verwerven (Kohn \& Schooler, 1982; Xanthopoulou et al., 2008).

Ten aanzien van de interventiepraktijk is vooreerst van belang te onderstrepen dat de werkkenmerken de belangrijkste voorspellers zijn van arbeidstevredenheid en bevlogenheid. Bij het bevorderen van die positieve werkuitkomsten zijn dus in de eerste plaats interventies in het werk zelf noodzakelijk, en dan vooral in het beschikbaar stellen van meer hulpbronnen. Van het verbeteren van de ontwikkelingsmogelijkheden mag de grootste winst verwacht worden. 
Echter, daarnaast onderstrepen de onderzoeksresultaten de gedachte dat een werksituatie niet zonder meer als een gegeven werkelijkheid gezien kan worden. Van belang is ook hoe een werknemer die werksituatie percipieert en ermee omgaat, en welke persoonsgebonden kenmerken daarop een invloed uitoefenen. In die zin ondersteunen de resultaten een pleidooi voor een meer interactionistische benadering van de werkplek: een werknemer dient de beschikbare hulpbronnen ook accuraat op te merken en ze inzetbaar maken voor het realiseren van de werkdoelen. In de mate dat persoonsgebonden kenmerken zoals een intrinsieke arbeidsoriëntatie, ertoe bijdragen dat de beschikbare opportuniteiten voor autonomie en ontwikkelingsmogelijkheden ook beter opgemerkt worden en effectiever benut worden voor het nastreven van de doelen, wordt de werksituatie en de bedreigende omstandigheden die erin aanwezig zijn, beter beheerbaar en beïnvloedbaar. 


\section{Literatuur}

Achterberg, P., Houtman, D., \& Jetten, B. (2003). Arbeidstevredenheid: een aanpassingsfenomeen? Tijdschrift voor Arbeidsvraagstukken, 19, 214-227.

Arbucle, J., \& Worthke, W. (1999). AMOS 4 user's reference guide. Chicago: Smallwaters Corporation.

Baker, S. (2004). Intrinsic, extrinsic, and amotivational orientations. Their role in university adjustment, stress, well-Being, and subsequent academic performance. Current Psychology, 23, 189-202.

Bakker, A., \& Demerouti, E. (2007). The job demands - resources model: State of the art. Journal of Managerial Psychology, 22, 309-328.

Bakker, A., Demerouti, E., \& Euwema, M. (2005). Job resources buffer the impact of job demands on burnout. Journal of Occupational Health Psychology, 10, 170-180.

Boer, F., De Jonge, J., \& Hamers, J. (2003). De relatie van werkkenmerken en bijpassende persoonskenmerken met psychisch welbevinden. Gedrag \& Organisatie, 16, 221-236.

Brief, A., \& Weiss, H. (2002). Organizational behavior: Affect in the workplace. Annual Review of Psychology, 53, 279-307.

Byrne, B. (2001). Structural equation modelling with Amos. Mahwah, NJ: Erlbaum.

Christian, M., \& Slaughter, J. (2007). Work engagement: A meta-analytic review and directions for research in an emerging area. In George T. Solomon (Ed.), Proceedings of the Sixty-Sixth Annual Meeting of the Academy of Management (CD), ISSN 1543-8643.

Deci, E., \& Ryan, R. (2000). The 'what' and 'why' of goal pursuits. Human needs and the selfdetermination of behavior. Psychological Inquiry, 11, 227-268.

De Lange, A., De Witte, H., \& Notelaers, G. (2008). Should I stay or should I go? Examining longitudinal relations among job resources and work engagement for stayers versus movers. Work \& Stress, 22, 1-23. 
Demerouti, E., Nachreiner, F., Bakker, A., \& Schaufeli, W. (2001). The job demands-resources model of burnout. Journal of Applied Psychology, 86, 499-512.

De Witte, H. (2000). Houdingen tegenover arbeid in België op de drempel van de eenentwintigste eeuw. In K. Dobbelaere, M. Elchardus, J. Kerkhofs, L. Voyé, \& B. BawinLegros (Red.). Verloren zekerheid. De Belgen en hun waarden, overtuigingen en houdingen (p.77-116). Tielt: Lannoo.

Diener, E., Larsen, R., \& Emmons, R. (1984). Person x situation interactions: Choice of situations and congruence response models. Journal of Personality and Social Psychology, $47,580-592$.

Evers, M., Ybema, J.F., \& Smulders, P. (2006). Arbeidstevredenheid: gevolg van werkkenmerken, werkwaarden of beide? Gedrag \& Organisatie, 19, 37-48.

Feather, N. (1992). Values, valences, expectations, and actions. Journal of Social Issues, 48, 109-124.

Feather, N. (1999). Values, achievement, and justice: Studies in the psychology of deservingness. New York: Kluwer Academic/Plenum.

Feather, N. \& O’Brien, G. (1986). A longitudinal study of the effects of employment and unemployment on school-leavers. Journal of Occupational Psychology, 59, 121-144.

Fredrickson, B. (2001). The role of positive emotions in positive psychology: The broadenand-build theory of positive emotions. American Psychologist, 56, 218-226.

French, J., Kaplan, R. \& Harrison, R. (1982). The mechanisms of job stress and strain. Chichester: Wiley.

Goudswaard, A., Dhondt, S., \& Kraan, K. (1998). Flexibilisering en arbeid in de informatiemaatschappij; werknemersvragenlijst, bestemd voor werknemers en bedrijven die deelnemen aan het SZW-Werkgeverspanel 1998. Hoofddorp: TNO Arbeid. 
Harrison, D., Newman, D., \& Roth, P. (2006). How important are job attitudes? Meta-analytic comparisons of integrative behavioral outcomes and time sequences. Academy of Management Journal, 49, 305-325.

Herzberg, F. (1959). The motivation to work. New York: John Wiley.

Hobfoll, S. (1989). Conservation of resources. A new attempt at conceptualizing stress. American Psychologist, 44, 513-524.

Hobfoll, S. (2002). Social and psychological resources and adaptation. Review of General Psychology, 6, 307-324.

Houkes, I., Janssen, P., De Jonge, J., \& Bakker, A. (2003). Personality, work characteristics, and employee well-being: A longitudinal analysis of additive and moderating effects. Journal of Occupational Health Psychology, 8, 20-38.

Houtman, I., Goudswaard, A., Dhondt, S., Van der Grinten, M., Hildebrandt, V., \& Kompier, M. (1995). Evaluatie van de monitorstudie naar stress en lichamelijke belasting. Den Haag: VUGA.

Judge, T., Bono, J., \& Locke, E. (2000). Personality and job satisfaction: The mediating role of job characteristics. Journal of Applied Psychology, 85, 237-249.

Kahn, W.A. (1990). Psychological conditions of personal engagement and disengagement at work. Academy of Management Journal, 33, 692-724.

Karasek, R. (1979). Job demands, job decision latitude, and mental strain: Implications for job redesign. Administrative Science Quarterly, 24, 285-307.

Karasek, R., \& Theorell, T. (1990). Healthy work: stress, productivity and the reconstruction of working life. New York: Basic Books.

Knoop, R. (2001). Relieving stress through value-rich work. The Journal of Social Psychology, $134,829-836$. 
Kohn, M., \& Schooler, C. (1982). Job conditions and personality: A longitudinal assessment of their reciprocal effects. American Journal of Sociology, 87, 1257-1286.

Lu, L. (1999). Work motivation, job stress and employees' well-being. Journal of Applied Management Studies, 8, 61-72.

May, D.R., Gilson, R.L., \& Harter, L.M. (2004). The psychological conditions of meaningfulness, safety and availability and the engagement of the human spirit at work. Journal of Occupational and Organizational Psychology, 77, 11-37.

Malka, A. \& Chatman, J. (2003). Intrinsic and extrinsic work orientations as moderators of the effect of annual income on subjective well-being: A longitudinal study. Personality and Social Psychology Bulletin, 29, 737-746.

Mauno, S., Kinnunen, U., \& Ruokolainen, M. (2007). Job demands and resources as antecedents of work engagement: A longitudinal study. Journal of Vocational Behavior, 70, 149-171.

Roberts, B. W. \& Robins, R. W. (2004). A longitudinal study of person-environment fit and personality development. Journal of Personality, 72, 89-110.

Schaufeli, W., \& Bakker, A. (2001). Werk en welbevinden. Naar een positieve benadering in de Arbeids- en gezondheidspsychologie. Gedrag en Organisatie, 14, 229-252.

Schaufeli, W., \& Bakker, A. (2004a). Bevlogenheid: een begrip gemeten. Gedrag \& Organisatie, $17,89-112$.

Schaufeli, W., \& Bakker, A. (2004b). Job demands, job resources, and their relationship with burnout and engagement: A multi-sample study. Journal of Organizational Behavior, 25, 293-315.

Schleicher, D., Watt, J., \& Greguras, G. (2004). Reexamining the job satisfaction-performance relationship: The Complexity of Attitudes. Journal of Applied Psychology, 89, 165-177.

Smulders, P., Andries, F., \& Otten, F. (2001). Hoe denken Nederlanders over hun werk? Opzet, kwaliteit en eerste resultaten van de TNO Arbeidssituatie Survey. Hoofddorp: TNO Arbeid. 
Steiger, J. (1990). Structural model evaluation and modification: An internal estimation approach. Multivariate Behavioral Research, 25, 173-180.

Taris, R., \& Feij, J. (2001). Longitudinal examination of the relationship between supplies-values fit and work outcomes. Applied Psychology: an International Review, 50, 52-80.

Van den Broeck, A., Vansteenkiste, M., De Witte, H., \& Lens, W. (2008). Explaining the relationships between job characteristics, burnout, and engagement: The role of basic psychological need satisfaction. Work \& Stress, 22, 277-294.

Van Hoof, J., Bruin, P., Schoemaker, M., \& Vroom, A. (2002). Werk(en) moet wel leuk zijn. Arbeidswensen van Nederlanders. Assen: van Gorcum.

Van Ruysseveldt, J., Smulders, P., \& Taverniers, J. (2008). De invloed van werkeisen en hulpbronnen op uitputting en bevlogenheid. Tijdschrift voor Arbeidsvraagstukken, 24, 226243.

Van Ruysseveldt, J., Taverniers, J., \& Smulders, P. (2009). De voorspelling van werkstress in Nederland en Vlaanderen. Tijdschrift voor Arbeidsvraagstukken, 25, 97-109.

Van Ruysseveldt, J., \& Smulders, P. (2008). Intrinsieke arbeidsoriëntatie en uitputting bij werknemers. Tijdschrift voor Arbeidsvraagstukken, 24, 266-287.

Van Ruysseveldt, J. (2006). Psychische vermoeidheid en plezier in het werk bij Vlaamse werknemers. Tijdschrift voor Arbeidsvraagstukken, 22, 328-343.

Vansteenkiste, M., Neyrinck, B., Niemec, P., Soenens, B., De Witte, H., \& Van den Broeck, A. (2007). On the relations among work value orientations, psychological need satisfaction and job outcomes: A self-determination theory approach. Journal of Occupational and Organizational Psychology, 80, 251-277.

Vroom, V. (1964). Work and motivation. New York: Wiley.

Warr, P. (1994). A conceptual framework for the study of work and mental health. Work \& Stress, 8, 84-97. 
Xanthopoulou, D., Bakker, A., Demerouti, E., \& Schaufeli, W. (2007). The role of personal resources in the job demands-resources model. International Journal of Stress Management, $14,121-141$.

Xanthopoulou, D., Bakker, A., Demerouti, E., \& Schaufeli, W. (2008). Reciprocal relationships between job resources, personal resources, and work engagement, Journal of Vocational Behavior (2008), doi: 10.1016/j.jvb.2008.11.003.

\footnotetext{
${ }^{1}$ In een deel van de onderzoeksliteratuur is ook wel de term 'werkwaarden' toegepast. Op grond van de begripsomschrijving aldaar zijn deze te beschouwen als synoniem voor arbeidsoriëntaties (zie Evers et al., 2006). ${ }^{2}$ Judge et al. (2000) beschrijven naar aanleiding van hun onderzoek naar de samenhang tussen core selfevaluations (CSE) en arbeidstevredenheid een vergelijkbaar zelfselectiemechanisme: personen met een positief zelfbeeld (hoge CSE) zijn meer geneigd complex werk te zoeken, meer inspanning in dergelijk complex werk te investeren zodat ze beter presteren en een hogere kans hebben het complexe werk te behouden of door promotie nog complexer werk te krijgen, en door hun hoger vertrouwen in eigen kunnen maken ze minder kans om te falen in complexe banen (Diener, Larsen \& Emmons, 1984).

${ }^{3}$ Xanthopoulou et al. (2007: 125) sluiten overigens niet uit dat persoonsgebonden hulpbronnen omgekeerd ook te beschouwen zijn als antecedenten van de werkkenmerken. Uitgaande van het Learning-Generalization Model van Kohn en Schooler (1982) poneren ze dat de verhouding tussen persoonsgebonden kenmerken en werkkenmerken als wederzijds geïnterpreteerd dient te worden. In een erg recent, longitudinaal opgezet onderzoek (Xanthopoulou et al., 2008) vinden ze daar ook empirische evidentie voor: het model dat het best fit met de data is het reciproke model waarin niet alleen de hulpbronnen en bevlogenheid, maar ook werkgerelateerde en persoonsgebonden hulpbronnen wederzijds samenhangen.

${ }^{4}$ Omdat vrouwen en jongeren ondervertegenwoordigd waren, is een aanvullende steekproeftrekking gedaan bij deze groepen (Evers, Ybema \& Smulders, 2006: 42). $\square$ De fitstatistieken voor model 1 zijn als volgt: $\chi^{2}=1794.39, \mathrm{df}=21, p<.001, \mathrm{CFI}=.65, \mathrm{NNFI}=.41 \mathrm{en}$ RMSEA $=.15(90 \% \mathrm{CI}=.14$ tot .15$)$.
} 